\title{
Citizens' Perceptions on the Role of Court Sentencing in Crime Control: A Survey of Mthatha High Court Juridical Area in South Africa
}

\author{
Anga Dlakulu, Ishmael Mugari ${ }^{*}$ and Emeka E. Obioha
}

Department of Social Sciences, Walter Sisulu University, Mthatha, South Africa

\begin{abstract}
For over a century, the role of court sentencing on crime deterrence has generated significant debate. In this study, we explored the citizens' perceptions on the role of court sentencing in South Africa's Mthatha area. The findings are looked in the context of the broad theories of punishment namely: retributive theory, deterrence theory, preventive theory, reformative theory and compensation theory. A total of purposefully sampled 90 respondents were invited to participate in this study through closed-ended questionnaires. The univariate perception results of the study reveal that reformation of the offender, protection of the offender from being harmed by the victim in retaliation, and ensuring that the victims get justice are the most significant roles of court sentencing. Collectively, the reality that severe sentence scares potential criminals not to commit crime stands out and is the most correlated role of court sentencing. Court sentencing was also viewed to be having two pronged preventive effect on criminal activities. First, the criminal is incapacitated from engaging in criminal activities during the time of imprisonment; and second, the offender is removed from the environmental factors that led to offending. As part of the conclusion, the study recommends sentencing policies that mainly support reformation of offenders.
\end{abstract}

Keywords: Court sentencing, crime deterrence, prevention, retribution.

\section{INTRODUCTION}

Sentencing in South Africa has recently been the focus of much attention in the media. There has been an outcry from the community, both for more stringent punishment and that offenders should serve a more realistic portion of the sentences imposed by courts of law. The public has also renewed claims for sentences which strike a balance between the desire for retribution, the concern for the reformation of offenders, and the concern for the protection of the public. There is also general dissatisfaction with the leniency of sentences imposed by the courts for serious crimes (Muthaphuli, 2012). The sentencing challenge in South Africa is compounded by the fact that the nation has what is known as an uncodified legal system consisting of various sources of law, including the Constitution, judicial precedent, customary law, common law (Roman-Dutch and English Law), and international law. As a result, there is absence of uniformity on sentencing, with concerns over the passing of different sentences for the same offence. There is wide public concern that courts are failing to give serious offenders punishment commensurate to their crimes (Roth, 2008). The end of death penalty in 1995 concomitantly created additional concerns regarding the punishment for murder which is the most serious offence. In

*Address correspondence to this author at the Department of Social Sciences, Walter Sisulu University, Mthatha, South Africa;

E-mail: ishiemugari@gmail.com addition, there is a widely held view that lenient parole policy allows early release of serious criminals. Whilst the debate on the efficacy of sentencing rages on, it is the society that bears the ultimate price if the sentencing fails to deter criminal activities.

In this study, we explore the citizens' perceptions on the role of court sentencing. The study was guided by the following research questions: what role does court sentencing play on crime and criminal behaviour? We explore these perceptions in the context of the broad theories of punishment namely: retributive theory, deterrence theory, preventive theory, reformative theory and compensation theory. Given that the society bears the consequences of most of the criminal activities, their views on sentencing matters are critical, which become helpful in shaping sentencing policies. Much of the literature on sentencing emanates from eminent criminologists as well as legal experts (for example; Meyer, 1969; Duff, 1986; Bargaric, 2001). Thus, this study adds to the ongoing debate about the efficacy of court sentencing on crime control from the citizens' perspective. The study also comes against a backdrop of a rise in criminal activities in South Africa on one hand and the growing public questioning of the court's role in controlling criminal behaviours, when citizens are dissatisfied with sentences being handed down by courts. The findings also shed more light on citizens' expectations regarding sentencing matters, where courts are seen to be the peoples' redeemers. 


\section{THE CONCEPT OF PUNISHMENT}

One way of guarding the rules that keep society together and providing us with a sense of security is through the institution of legal punishment: a means by which suitable and just reactions are meted out to those who infringe the rules (Mugari, 2021). Thus, the fear of acts which disrupt social equilibrium has inspired the imposition of punishment by those who have the power to establish and enforce the desired standards of conduct (Meyer, 1969). Punishment is a diverse concept, which is difficult to define as well. Duff (1986) defines punishment as "the infliction of suffering on a member of the community who has broken its laws". Similarly, Bagaric (2001) provides a minimalistic definition as follows: "punishment is a hardship or deprivation; the taking away of something of value for a wrong actually or perceived to have been committed". As Obioha (2002) argued, punishment has two crucial elements, "desert" and "displeasure". "Desert" suggests that the consequent event or punishment was in some degree a removal or detachment of the culprit from his crime. The second element "displeasure" on the other hand implies that the consequent event was displeasurable and painful to the culprit as a social balance to his crime. Notwithstanding their simplicity, these perspectives, however, do not capture all the essentials of punishment. The most influential definition of punishment has been provided by Professor Andrew Flew (1954), who argued that, for an act to be defined as a punishment, it must conform to five basic rules. The penal sanction must: 1) create human suffering; 2 ) arise as a direct result of the perpetration of an offence; 3 ) only be directed at the person who under took the offence, i.e. the offender; 4) be the intentional creation of other humans in response to that offence; and 5) be inflicted by an authorised body representing the embodiment of the rules or laws of the society in which the offence was committed (Flew, 1954). The foregoing according to Obioha (2002) boil down to the notion of punishment as pain, or displeasure consequent upon a behaviour that was either unreasonable, unwarranted or done with utmost negligence of instructions or rules of the society.

\section{THE THEORIES OF PUNISHMENT}

Philosophers and penologists have over the years advanced diverse explanations or justifications for punishment. There is no consensus on which explanations or theory best justifies punishment in society. These explanations vary from the psychological, sociological, physiological to medical underpinnings as the members of the society may interpret the action of the offender (Obioha, 1994). In considering what should be done to the offenders, these contextual explanations should be well understood. It is clear from both theoretical and empirical evidence that there are many reasons for crime. Therefore, the ways society seeks to punish offenders must, if they are to be effective, be varied and flexible in nature (Obioha, 2002). Carabine et al. (2009) and Cavadino et al. (2013) proffer two broad justifications for punishment, namely; retribution and reductivism. Retribution justifies punishment on the ground that it is deserved by the offender, while reductivism justifies punishment on the ground that it helps to reduce the incidents of crime. Cohen (1981) avers that criminal punishment must serve a number of social goals: the rehabilitation of the offender, deterrence, retribution and the protection of society. None of these are pre-eminent; hence the sentencing judge must accommodate these competing demands. From the social goals of punishment come the five theories of punishment namely: retributive theory, deterrent theory, preventive theory, reformative theory, and compensation theory (Mugari, 2021). In the section that follows, we look at these five theories of punishment, which informed this study.

\section{Retributive Theory}

Retribution is probably the oldest and most ancient justification for punishment, according to which a wrong is made right by an offender's receiving his 'just desert'. Ordinarily, the instinctive reaction to criminal acts is retaliation by the injured person. Hence, retribution is a form of vengeance, a way of releasing and expressing hostility towards the criminal and his conduct (Meyer, 1969). All retributive theorists assert that offenders deserve to suffer, and that the institution of punishment should inflict the suffering they deserve (Bargaric, 2001). Put in simple terms, retribution basically means that the offender pays for his wrongdoing, and the offender should receive as much pain and sufferings as inflicted by him on his victim. Thus, 'teeth for teeth', 'eye for eye' are the basic principle of this theory (Mishra, 2016). Whereas other theories of punishment regard punishment as a means to an end, the retributive theory looks at punishment as an end in itself. Thus, it is perfectly legitimate that evil should be returned for evil, and that a man should be dealt with in the manner in which he deals with others (Mugari, 2021). 


\section{The Deterrent Theory}

Deterrence is the use of punishment to prevent the offender from repeating his offense and to demonstrate to other potential offenders what will happen to them if they follow the wrongdoer's example (Meyer, 1969; Carrabine et al., 2009). First, it is held that the experience of punishment will deter offenders from committing further crimes, as they will now be aware of the unpleasant consequences that will follow should they again be apprehended and sentenced. Second, it is claimed that the sight of offenders being punished will deter other potential lawbreakers, as it will serve as an example of the dictum that 'crime doesn't pay' (O'Brien \& Yar, 2008). Thus, punishment is primarily deterrent when its object is to show the futility of crime, and thereby teach a lesson to others. The object of punishment, according to this theory, is to show that in the final analysis, crime is never profitable to the offender, and as Locke observed, to make crime an illbargain to the offender. By making it an ill-bargain to the offender, the world at large would learn that crime is a costly way of achieving an end. At the heart of punishment as deterrence is a rational choice model of action, one that supposes that individuals will weigh up the likely costs and benefits of lawbreaking before choosing whether or not it is in their interests to act (O'Brien \& Yar, 2008). Provided that the punishment is sufficiently severe and likely to occur, individuals will decide that the costs (pain, suffering, deprivation, and loss of liberty) outweigh the gains and choose not to offend (Mugari, 2021).

\section{The Preventive Theory}

Proponents of this theory hold that the object of punishment is to prevent offences and the offences can be prevented when the offender and his notorious activities are checked (Bagaric, 2001; Siegel, 2010). Punishment is meant to restrain an offender personally from repeating a criminal act by incapacitating him. Thus, an offender's ability to commit further crimes should be removed, either physically or geographically (through locking them up, removing offending limbs or killing them) (Carrabine et al., 2009). In this regard, imprisonment is the sentencing option that most effectively prevents re-offending. With imprisonment, the offender is away from the society, and hence he has no chance of committing the crime as he is not free (Shelke \& Dharm, 2019). If the deterrent theory tries to put an end to crime by causing fear of the punishment on the mind of the possible offender, the preventive theory aims at preventing crime by disabling the criminal.

\section{The Reformative Theory}

The theory is based on the idea that punishment can reduce crime if it takes a form that will improve the individual's character so that they are less likely to reoffend in the future (Bagaric, 2001). This theory believes in the concept that "hate the crime not the criminal" and that nobody is born a criminal- it is only the consequences of those circumstances which were around of him; so situations and circumstances can be changed (Mishra, 2016). Because society has failed them, many offenders have been forced to grow up in disorganized neighbourhoods, have been the target of biased police officers, and are disadvantaged at home, at school, and in the job market (Siegel, 2010). To compensate for these deprivations, the justice system is obligated to help these unfortunate people and not simply punish them for their misdeeds (Bushway, 1998). Rehabilitation advocates believe that if the proper treatment is applied, an offender will present no further threat to society. It is motivated by a belief in the worth and dignity of every person and a willingness of society to expend its time and energy to reclaim him for his own sake, not merely to keep him from harming society (Meyer, 1969). Consequently, this is virtually not a punishment, but a mere rehabilitative process. It aims at making the criminal as far as possible a better citizen by means of moral and ethical training, that is, teaching him to be an upright man and meaningful citizen. The theory would consider punishment as a curative measure which has to perform the function of a medicine, given the theory's proposition that crime is like a disease (Shelke \& Dharm, 2019).

\section{The Compensation Theory}

Because criminals gain from their misdeeds, it seems both fair and just to demand that they reimburse society for its loss caused by their crimes (Siegel, 2010). This theory propounds that the object of punishment must not be merely to prevent further crimes, but also to compensate the victim of the crime. This theory is premised on the belief that the mainspring of criminality is great and if the offender is made to return the ill-gotten benefits of the crime, the spring of criminality would be dried up. To this end, the sentencing should also take into cognisance the aspect of compensating the victims of crime (Mugari, 2021). The goal of this theory of punishment means that convicted criminals must pay back their victims for their loss, the justice system for the costs of processing their case, and society for any disruption they may have caused. To help defray these costs, convicted 
offenders might be required to pay a fine, forfeit the property they acquired through illegal gain, do community service work, make financial restitution to their victim, and reimburse the state for the costs of the criminal process (Sigel, 2010). Because the criminals' actions helped expand their personal gains, rights, and privileges at society's expense, justice demands that they lose rights and privileges to restore the social balance (Mugari, 2021).

\section{METHODOLOGY}

\section{Area of Study and Sampling}

This study was conducted in Mthatha High Court Juridical area. Mthatha is one of the most populated towns in the Eastern Cape Province, with a population of 210 783. It is the main town of King Sabata Dalindyebo Local Municipality (KSD), and the capital of OR Tambo District Municipality. The area is home to people of different races who include Africans, Whites, Coloureds and Indians. The data for this study were collected from a sample of 90 respondents who voluntarily participated in the study. This set of respondents, from age 18, and including all races was selected from a large population of Mthatha policing area. Purposive sampling and snowball sampling techniques were used to select respondents. The researchers first identified key respondents based on their perceived appreciation of court sentencing issues. From these key informants, researchers were referred to other participants.

\section{Instrument and Data Analysis}

A quantitative research design in the form of a survey was used, wherein data were gathered through closed-ended questionnaires. The questionnaire was divided into two sections. Section A of the questionnaire dealt with the demographic variables. Section B dealt with the independent variables, which comprised of eight assertions on the role of court sentencing. The respondents were asked to indicate their level of agreement to the given assertions on a 4point Likert scale. Responses were fed into the Statistical Package for Social Sciences (SPSS) for analysis, with the data being presented on a table to reveal descriptive statistics and inferential statistics.

\section{RESEARCH FINDINGS}

\section{The Role of Court Sentencing}

The statement that criminals are sentenced to imprisonment so as to alter their criminal behaviour was considered as the most significant role of court sentencing, with an overwhelming majority $(91 \%)$ either agreeing or strongly agreeing to the assertion. The assertion had a mean of 3.13 (Table 1). This was followed by the assertion that punishment by the court of law prevents the offenders from being harmed by the victim. The assertion had a mean of 2.98 , with $80 \%$ of the respondents either agreeing or strongly agreeing to the assertion. The assertion that court sentence ensures that the victims get the justice they need by punishing offenders came third, with a mean of 2.96 and $77 \%$ of the respondents were inclined to agree with the assertion. This was followed by the assertion that most criminals are sentenced to imprisonment to prevent them from committing any more crime and the assertion had a mean of 2.82 , with $71 \%$ of the respondents either agreeing or strongly agreeing to the assertion.

The assertion that criminals are removed from the society so that they can be away from the things that are triggering them to commit crime had a mean of 2.80 and two thirds of the respondents were inclined to agree with the assertion. This was followed by the assertion that criminals get scared to commit crime because they don't have means of paying back what has been damaged, with a mean of 2.56 and $58 \%$ of the respondents being inclined to agree with the assertion. The assertion that most criminals decide to change their lives after being sentenced and become better people within their communities had a mean of 2.52. Half of the respondents were inclined to agree with the assertion. The assertion that most potential criminals get scared of committing crime when the court sentence is severe was the least popular assertion, with a mean of 1.84 and majority of the respondents were inclined to disagree with the assertion.

The following are the results that came out when the chi-square test was performed on the statements; Most potential criminals get scared of committing crime when the court sentence is severe: $x^{2}=13.067$; the degree of freedom for the test is 2; the corresponding $p$-value $=0.001$. Most criminals are sentenced to imprisonment to prevent them from committing any more crime: $x^{2}=39.244$; the degree of freedom for the test statistics is 3 ; the corresponding $p$-value is $p<0.001$. Criminals are removed from the society so that they can be away from the things that are triggering them to commit crime: $x^{2}=48.756$; the degree of freedom is 3 ; the $p$-value is $p<0.001$. Criminals are sentenced to imprisonment so as to alter their criminal 
Table 1: Results of the Chi-Square Test on the Purposes of Court Sentencing in South Africa

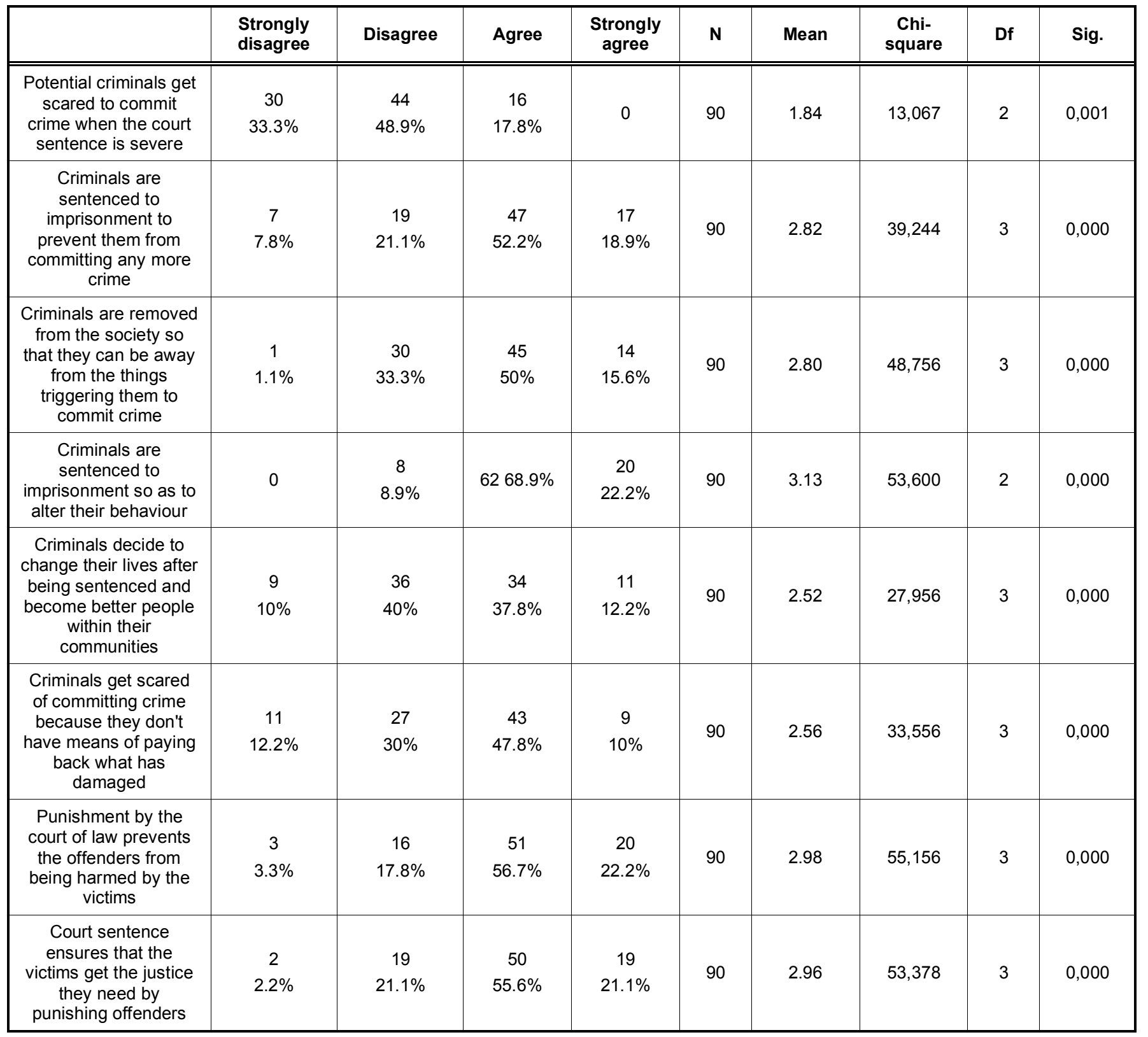

behaviour: $x^{2}=53.600$; the degree of freedom is 2 , and the $p$-value is $p<0.001$. Most criminals decide to change their lives after being sentenced and become better people within their communities: $x^{2}=27.956$; the degree of freedom (df) is 3 ; the $p$-value is $p<0.001$. Criminals get scared of committing crime because they don't have means of paying back what has been damaged: $x^{2}=33.556$; the degree of freedom (df) $=3$; and the value of $P<0.001$. Punishment by the court of law prevents the offenders from being harmed by the victim: $x^{2}=55.156$, the degree of freedom (df) $=3$; and the value of $p<0.001$. Court sentence ensures that the victims get the justice they need by punishing offenders: $x^{2}=53.378$; the degree of freedom $(d f)=3$; and the value of $P<0.001$. Mathematically, it is said that the smaller the $p$-value the more significant the results are. Therefore it can be concluded that since the $p$ value is less than the chosen significance level which is $\mathrm{P}<0.05$ in all the statements on the table above (Table $1)$, it shows that the results are significant.

\section{DISCUSSION OF FINDINGS}

Findings from this study reveal that majority of the respondents are of the view that criminals are sentenced to imprisonment to alter their criminal behaviour. It can be argued that the finding suggests that court sentencing helps to reform the criminal, in 
consonance with the reformative theory of punishment. As argued by Shelke \& Dharm (2019), punishment should be seen as a curative measure which has to perform the function of a medicine. Thus, altering the criminal behaviour will be akin to taking curative measures. This argument is also supported by the majority's agreement to the assertion that criminals decide to change their lives after being sentenced and become better people within their communities. Previous researchers (for example, Meyer, 1969; Bagaric 2001; Mishra, 2016) have also argued that punishment can reduce crime if it takes a form that will improve the individual's character so that they are less likely to reoffend in the future. From another perspective, altering criminal behaviour can also be construed from a deterrent perspective. Given that individuals will weigh up the likely costs and benefits of lawbreaking before choosing whether or not it is in their interests to act (O'Brien \& Yar, 2008), punishment or the threat of punishment will increase the costs of lawbreaking, thus causing criminals to alter their criminal behaviour.

Findings also reveal that respondents do not support private vengeance, as shown by the majority's view that punishment by the court of law prevents the offenders from being harmed by the victim. This finding can be attributed to the high levels of vigilantism in South African societies, coupled by high crime rates and the perceived inability of the Police Service to tackle the crime problem. As a result, citizens take the law into their own hands and mete out street justice on criminals. Thus, sentencing the criminal to imprisonment will protect the criminal from being harmed by the victim or the community. Closely related to this is the majority's belief that court sentence ensures that the victims get the justice they need by punishing offenders. This resonates with the retributive theory, which avers that the offender should receive as much pain and sufferings as inflicted by him on his victim (Bargaric, 2001; Mishra, 2016). Thus, the mere fact of seeing an offender being sent to jail will not only bring closure to the victims but will also remove the urge for private vengeance. The finding on retribution seems to resonate with the general concern that criminals are receiving lenient sentences for serious crimes in South Africa.

Another objective of punishment as revealed by the findings is prevention, as shown by the majority's agreement to the assertion that most criminals are sentenced to imprisonment to prevent them from committing any more crime. As argued by the proponents of the preventive theory (for example: Bagaric, 2001; Carrabine et al., 2009; Siegel, 2010), the object of punishment is to restrain an offender personally from repeating a criminal act by incapacitating him. Thus, during the time when the offender is serving a prison term, the prison confinement will prevent him from committing further criminal activities. Closely related to this is the view that criminals are removed from the society so that they can be away from the things that are triggering them to commit crime. Given that crime can be triggered by a myriad of factors such as poverty, bad social influences, greed, among others, imprisonment removes the offenders from these factors, thus preventing them from engaging in criminal activities. Consequently and as noted by Shelke \& Dharm (2019), imprisonment takes the offender away from the society, hence removing the chances of committing crime. Lastly, findings also revealed that respondents consider compensation as another role of punishment, as shown by the agreement to the assertion that criminals get scared to commit crime because they don't have means of paying back what has been damaged. This shows that there is a belief among citizens that criminals are ordered to compensate the victims as part of the sentence. While previous researchers argued that it is fair and just for criminals to reimburse society for losses caused by their crimes (Siegel; 2010; Mugari, 2021), the respondents considered the aspect of compensation from a deterrent and preventive perspective. Thus, the fact that offender will not be able to compensate the victims will deter him from engaging in criminal activities.

\section{CONCLUSIONS}

Notwithstanding the general concern over lenient sentences for serious offences in South Africa as noted in the introductory section of this paper, results of this study reveal that reformation is considered as the most significant role of court sentencing. Respondents believe that court sentencing will help the criminals to alter their criminal behaviour and the altering of criminal behaviour also plays a key role on crime deterrence. In what seems to be tacit concern over the welfare of the criminals, findings also reveal that court sentencing will help to protect the offenders from victims. Such a finding can be attributed to the rise in vigilant activities that characterise the South African nation. From the retribution perspective, findings also reveal that court sentencing ensures that the victims get the justice they need by punishing offenders. Notwithstanding the view that offenders should receive as much pain and 
sufferings as inflicted by him on his victim, respondents believe that such pain and suffering should not be inflicted by the victims. Court sentencing was also viewed to be having a preventive effect on criminal activities. The preventive effect is two pronged: first, the criminal is incapacitated from engaging in criminal activities during the time of imprisonment; and second, the offender is removed from the environmental factors that led to offending. From the results of the findings, it can be argued that the sentencing policies should mainly revolve around the reformation of the offender, though the other objectives of sentencing should also be taken into consideration.

\section{REFERENCES}

Bagaric, M. 2001. Punishment and Sentencing: A Rational Approach. London: Cavendish Publishing Limited.

Bushway, S. 1998. The Impact of an Arrest on the Job Stability of Young White American Men. Journal of Research in Crime and Delinquency, 35, 454-479. https://doi.org/10.1177/0022427898035004005

Carrabine, E, Cox P., Lee, M., Plummer, K., \& South, N. 2009. Criminology. A Sociological Introduction.: London: Routlege. https://doi.org/10.4324/9780203884942

Cavadino, M., Dignan, J., \& Mair, G. 2013. The penal System: An Introduction, $5^{\text {th }}$ Edition. Los Angeles: Sage.

Cohen, S. A. 1981. An introduction to the theory, justifications and modern manifestations of criminal punishment. McGill Law Journal, 27, 73-91.
Duff, R.A. 1986. Trials and Punishments. Cambridge: Cambridge University Press.

Flew, A. 1954. The justification of punishment, in H.B. Acton (ed). The Philosophy of Punishment. London: Macmillan, pp. 83101.

Meyer, J. 1969. Reflections on some Theories of Punishment. Journal of Criminal Law and Criminology, 59 (4): 595- 598. https://doi.org/10.2307/1141839

Mishra, S. 2016. Theories of punishment. A philosophical aspect. Imperial Journal of Interdisciplinary research (IJIR), 2 (8), 7478.

Mugari, I. 2021. An introduction to criminological theory, penology and crime prevention. New York: NOVA Science Publishers.

Muthaphuli, P. 2012. Crime prevention and sentencing: A practical penological perspective. Thesis: University of South Africa.

Obioha, E.E. 1994. Punishment and Its Objectives. Paper presented at the Postgraduate Seminar Series. Department of Sociology, University of Ibadan.

Obioha, E.E. 2002. Punishment in Society. In: UC Isiugo-Abanihe, AN Isamah, O Adesina 'Jimi'(Eds.): Currents and Perspectives in Sociology. Lagos: Malthouse Press Limited, pp. 367-379.

O'Brien, M., \& Yar, M. 2008. Criminology: The key Concepts. London: Routledge. https://doi.org/10.4324/9780203895184

Roth, S. M. 2008. South African mandatory minimum sentencing: Reform required. Minnesota Journal of International Law, 111. https://scholarship.law.umn.edu/mjil/111.

Shelke, S., \& Dharm, J. 2019. Theories of punishment: changing trends in penology. International Journal of Engineering and Advanced Technology, 8 (6): 1299-1301. https://doi.org/10.35940/ijeat.F1225.0986S319

Siegel, L.J. 2010. Introduction to Criminal Justice. USA: Wadsworth, Cengage Learning.

(c) 2021 Dlakulu et al.; Licensee Lifescience Global.

This is an open access article licensed under the terms of the Creative Commons Attribution License (http://creativecommons.org/licenses/by/4.0/) which permits unrestricted use, distribution and reproduction in any medium, provided the work is properly cited. 